\title{
Relationship between Frontal Qrs-T Angle and Myocardial Perfusion Defect (Mpd) from Single Photon Emission Computed Tomography (Spect) in Patients with Prior Myocardial Infarction
}

Vitri Alya*, Harris Hasan*, Zainal Safri, Zulfikri Mukhtar, Andika Sitepu, Ali N Nasution

Department of Cardiology and Vascular Medicine, Faculty of Medicine, Universitas Sumatera Utara / Haji Adam Malik General Hospital, Medan, North Sumatera, Indonesia

\section{ARTICLE INFO}

*Corresponding author

Email:

hasan1956@yahoo.com

allyya.143@gmail.com

Address:

Jalan Rawa Cangkuk IV No. 24, Kota Medan

Keywords:

STEMI; frontal QRS-T angle; myocardial perfusion defect.

Manuscript submitted: September 9, 2020

Revised and accepted: October 4, 2021

\begin{abstract}
Background: The frontal QRS-T angle is the angle between ventricular depolarization and repolarization. The QRS-T angle abnormalities will mirror the electrical instability, placing the patient in high risk of cardiac arrhythmia and sudden cardiac death. This study was conducted to analyzed as if the QRS-T angle will predict the myocardial perfusion defect in acute ST elevation myocardial infarction (STEMI).
\end{abstract}

Methods: This is a cross sectional study which conducted in patients with previous history of STEMI in H. Adam Malik General Hospital Medan from June 2018 until March 2020. The patients will then be undergoing electrocardiography (ECG) and myocardial perfusion scintigraphy (SPECT) to acquire the frontal QRS-T angle and myocardial perfusion defect score.

Results: Over 40 patients with prior STEMI we found the frontal QRS-T angle has a positive moderate correlation $(r=0,543$; $p<0,001)$ with myocardial perfusion defect. The best cut-off value for frontal QRS-T angle to predict myocardial perfusion defect is $\geq 70^{\circ}$ with sensitivity and specificity of $70.6 \%$ and $82.6 \%$, respectively.

Conclusions: The frontal QRS-T angle is an independent predictor for myocardial perfusion defect in patient with previous history of STEMI.

\section{INTISARI}

Latar Belakang: Sudut gelombang QRS - T bidang Frontal merupakan sudut antara arah depolarisasi dan repolarisasi ventrikel. Kelainan pada sudut QRS$\mathrm{T}$ dapat mencerminkan ketidakstabilan listrik, menempatkan pasien pada risiko tinggi untuk aritmia ventrikel dan kematian jantung mendadak. Tujuan penelitian ini adalah untuk mengetahui apakah Sudut Gelombang QRS - T bidang Frontal dapat memprediksi defek perfusi miokard pada pasien infark miokard akut dengan elevasi segmen ST (IMA-EST).

Metode: Penelitian ini merupakan suatu studi potong lintang terhadap pasien dengan riwayat IMA-EST di Rumah Sakit H. Adam Malik Medan sejak Juni 2018 sampai maret 2020. Subjek selanjutnya dilakukan elektrokardiografi (EKG) dan sidik perfusi miokard (SPECT) untuk mendapatkan sudut QRS-T bidang frontal dan nilai defek perfusi miokard.

Hasil: Dari 40 orang pasien dengan riwayat IMA-EST didapatkan sudut gelombang QRS - T bidang frontal memiliki korelasi positif dengan kekuatan korelasi moderate $(r=0,543 ; p<0,001)$ terhadap defek perfusi miokard. Titik potong sudut gelombang QRS-T terbaik dalam memprediksi 
defek perfusi miokard yaitu $>70^{\circ}$ dengan sensitifitas $70,6 \%$ dan spesifisitas $82,6 \%$.

Kesimpulan: Sudut gelombang QRS - T bidang frontal merupakan penentu independent untuk defek perfusi miokard pada pasien dengan riwayat IMAEST.

\section{Introduction}

Coronary artery disease is a major cause of death among individuals around the world. In China, every year cases of coronary artery disease and its mortality increased. Acute coronary syndrome is a severe type of coronary artery disease which should diagnosed rapidly, treated with antiplatelet and needed early revascularization. ACC/ AHA and ESC has reported an importance of early diagnosis and revascularization benefits. The treatment based on CAD therapeutic guidelines can reduce mortality. Hospitals and primary health created Coronary Care Unit (CCU) to treat patients with high mortality of CAD, such as STEMI and NSTEMI. In 2013, the prevalence rate of coronary artery disease was 0,5\% among 883.447 people. The prevalence rate of coronary artery disease based on doctor diagnosis and patient symptoms was 1,5\% among 2.650 .340 people. ${ }^{2}$

Left ventricle disfunction remains one of the best prognostic determinants of survival in the patient with coronary artery disease. The myocardial injury occurred after permanent infark primarily. However, some of myocardial tissue remained viable and contractility may be restored after revascularization. The left ventricle systolic function, which reduced due to ischemia, will show a worse outcome. However, not every myocardium improves with revascularization, viability testing has been studied and utilized. $^{3}$ Single-Photon Emission CT (SPECT) used radionuclide-labelled tracer to measure the regional tracer of myocardiac and measure viability by determining percentage of peak uptake of the tracer. This can be interpreted with rest images only or stress/rest testing protocol. The most common tracer used are $99 \mathrm{mTc}$-sestamibi or ${ }^{201} \mathrm{TI}$. Both tracers have been shown to have comparable result in predicting recovery of resting defect. The radiotracers absorbed into the myocyte with intact cell membrane. The prognostic value of single-photon emission computed tomography myocardial perfusion imaging (SPECT MPI) has been shown better in patient with suspected or confirmed CAD and patient with STEMI, which was treated by trombolysis. ${ }^{4}$

The frontal QRS-T angle (FQRST), defined as the absolute difference between the QRS and T-wave axis in 12-leads ecg, is a sign of ventricle repolarization. The abnormality of QRS$\mathrm{T}$ shows an unstability of electrical impulses, which categorized patients as high risk of ventricular arrythmia or sudden death. Although myocardial infarct is a major structural heart disease that can change ventricular repolarization, the relationship between severity of perfusion myocardiac defect and QRS-T angle still need a further study. Myocardial perfusion, which determined by SPECT and ECG, is a unique modality to evaluate myocardial perfusion and left ventricular function simultanly. In this study, we tried to evaluate the effect of myocardial perfusion defect in frontal QRS-T angle and myocardial perfusion by SPECT in coronary artery disease. ${ }^{5}$

\section{Study Design and Population}

This study was a cross sectional study which evaluated frontal QRS-T angle from electrocardiography as a diagnostic parameter of myocardial infarct area using myocardial SPECT in STEMI patient. We evaluated 40 patients with previous STEMI, which the first onset occurred within 12 months before, using cardiac SPECT imaging in Haji Adam Malik General Hospital. The subject collected during June 2018 - March 2020. The inclusion criteria were patient with previous STEMI, which the first onset occurred minimum since 12 months ago, agreed to perform SPECT and approved to sign the informed consent. The exclusion criteria were patient with bundle branch block (BBB), patient with severe valve disease, patient with Coronary Artery Bypass Graft history, patient with worsen heart failure symptoms during SPECT procedure.

\section{Single-Photon Emission Computed Tomography Myocardial Perfusion Imaging (SPECTMPI)}

Cardiac SPECT procedure using radio pharm 1 day Tc-99m Sestamibi protocol with pharmacological stress express by Dobutamine. SPECT procedure performed with ECG gated rotating $90^{\circ}$ fixed dual-head gamma camera (Philips Medical System, Cleveland). We used 5-10 mcg/kg/min intravenous dobutamine within 3 minutes interval up to maximum dosage $40 \mathrm{mcg} / \mathrm{kg} / \mathrm{min}$. The radio pharm was injected during the peak of heart rate $(85 \%$ from maximum predicted heart rate) and intravenous dobutamine continued a minute after the injection. The procedure would be stopped if the patient had worsened symptoms (such as chest pain, vertigo, sweating, tachycardia or shortness of breath), hemodynamic disturbance, or malignant ECG changes and the patient would be excluded.

\section{Analysis of myocardial perfusion by SPECT}

By performing SPECT procedure, we analyzed myocardial perfusion by visualized assessment and semiquantitative score. The result would be analyzed by AutoQuant software developed by Cedars-Sinai Medical Centre (Los Angeles, California). Semiquantitative score included Summed Stress Score (SSS), Summed Rest Score (SRS) and Summed Difference Score (SDS), which could be related in this formula SDS = SSS- SRS. Summed Redistribution Score (SRS) is a score which can be used to evaluate the percentage of myocardial perfusion defect using this formula; MPD (\%) = SRS $x$ 100.68. The result of SPECT would be interpreted by Nuclear Specialist and Cardiologist. 


\section{Electrocardiography (ECG)}

Electrocardiography was recorded with paper speed 25 and $50 \mathrm{~mm} / \mathrm{sec}$ and an amplification $10 \mathrm{~mm} / \mathrm{mV}$ in supine position. QRS-T angle measurement was performed by calculated the difference between QRS axis and T wave axis in lead I and aVF. The calculation was performed by using millimeter block, or could be found in ECG machine using Bionet Cardiotouch 3000 electrocardiography. The result of QRS-T angle that we count by using millimeter block were validated by two cardiology consultants.

\section{Data analysis}

Categorical variable is shown as frequencies and percentages. Numeric variables are shown as mean and standard deviation. The Spearman correlation were performed to analyze the correlation of frontal QRS-T angle with Summed Redistribution Score (SRS). If the correlation shown a significant relationship between the variables, cutoff point would be analyzed using ROC (Receiver Operating Characteristic). The cut-off point of frontal QRS-T angle would be used to analyzed the area of infarct in cardiac SPECT. Bivariate analysis was performed to analyzed the frontal QRS-T angle with myocardial perfusion scintigraphy parameters using SPECT by Chi-square and Fisher's Exact Test. The T-independent test were assessed to measure the cathacteristics difference in normally distributed data. In contrary we used Mann Whitney test to analyzed the nonnormally distributed data. The statistic was performed by statistical software. The analysis was considered statistically significant if the p value $<0.05$.

\section{Results}

The study was included 40 patients with STEMI that fulfil the inclusion criteria. The majority gender of subjects was 39 male (95\%) whose age between $54,6 \pm 7,32$ years. The patients with anterior STEMI were 26 people $(65 \%)$ and inferior STEMI were 14 people (35\%). Based on risk factors characteristics, Patients with Diabetes Mellitus were 18 people (45\%), 26 people were dealing with hypertension (65\%), 36 people were smokers (90\%). Patient with CAD3VD were 19 people $(47,5 \%)$. Based on SPECT myocardial perfusion data, the mean of SSS was 19,9 $\pm 10,57$ with the mean of $\%$ SS $28,9 \pm 15,52$. Whereas, the SRS mean was $15,7 \pm 9,86$ with mean RS (MPD) 22,9 $\pm 14,50$, and SDS was SDS 3,5 $\pm 3,21$ with mean \%DS $4,9 \pm 4,7$. The frontal QRS-T angle mean by ECG was 66,8 \pm 40,39 with mean ejection fraction $44,2 \pm 11,79$. Patients who performed revascularization were 21 people $(52,5 \%)$. The revascularization time $>12$ hours were 16 people $(40 \%)$. Patient with revascularization time $<12$ hours were 5 people $(12,5 \%)$. (Table 1 )

The ROC curve analysis was performed to assess the cutoff point of FQRST angle to predict infarct area (MPD). The area under the curve (AUC) was $79,7 \%$. FQRST angle $\geq 70^{\circ}$ has a $70,6 \%$ sensitivity and $82,6 \%$ specificity to predict large infarct area (MPD > 22,8). (Figure 2) (Table 2)
Pearson Corelation analysis was performed to show a relationship of FQRST with MPD. We found a positive corelation between FQRST and MPD. (Figure 1)

Table 1. Baseline Characteristics

\begin{tabular}{|c|c|}
\hline Characteristics & $\mathbf{N}=40$ \\
\hline Age & $54,6 \pm 7,32$ \\
\hline \multicolumn{2}{|l|}{ Gender } \\
\hline Male & $38(95 \%)$ \\
\hline Female & $2(5 \%)$ \\
\hline \multicolumn{2}{|l|}{ Diagnosis } \\
\hline STEMI Inferior & $14(35 \%)$ \\
\hline STEMI Anterior & $26(65 \%)$ \\
\hline \multicolumn{2}{|l|}{ Risk Factor } \\
\hline Diabetes Mellitus & $18(45 \%)$ \\
\hline Hypertension & $26(65 \%)$ \\
\hline Smoker & $36(90 \%)$ \\
\hline CAD3VD & $19(47,5 \%)$ \\
\hline \multicolumn{2}{|l|}{ SPECT } \\
\hline SSS & $19,9 \pm 10,57$ \\
\hline$\% \mathrm{SS}$ & $28,9 \pm 15,52$ \\
\hline SRS & $15,7 \pm 9,86$ \\
\hline$\%$ RS (MPD) & $22,9 \pm 14,50$ \\
\hline SDS & $3,5 \pm 3,21$ \\
\hline$\%$ DS & $4,9 \pm 4,7$ \\
\hline FQRST & $66,8 \pm 40,39$ \\
\hline $\mathrm{EF}$ & $44,2 \pm 11,79$ \\
\hline$\geq 50 \%$ & $17(42,5 \%)$ \\
\hline$<50 \%$ & $23(52,5 \%)$ \\
\hline Revascularization & $21(52,5 \%)$ \\
\hline$>12$ hours & $16(40 \%)$ \\
\hline$<12$ hours & $5(12,5 \%)$ \\
\hline
\end{tabular}

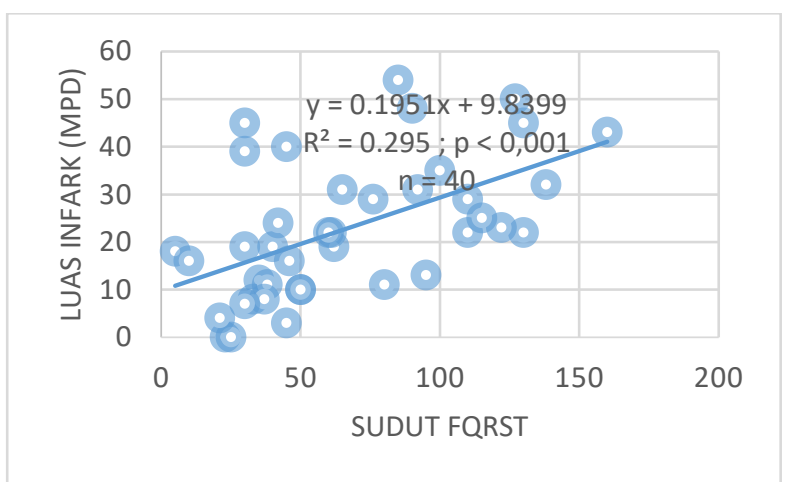

Figure 1. Scatter Plot Chart of FQRST with \%RS (MPD)

The mean of FQRST angle patient with reduced $\mathrm{EF}(\leq 50 \%)$ was $84,24 \pm 40,35$. The mean of FQRST angle with preserved $\mathrm{EF}(>50 \%)$ was $37,80 \pm 17,54$ with $\mathrm{p}$ value $<0,001$. The mean of FQRST angle with anterior area was72,5 $\pm 41,75$ with mean of inferior area 56,2 $\pm 36,82$ (p $=0,227$ ). Whereas, the mean of FQRST angle who have been performed revascularization was $64,8 \pm 44,53$, and 69,1 \pm 36,34 with patient who did not undergone revascularization $(\mathrm{p}=0.227)$. 


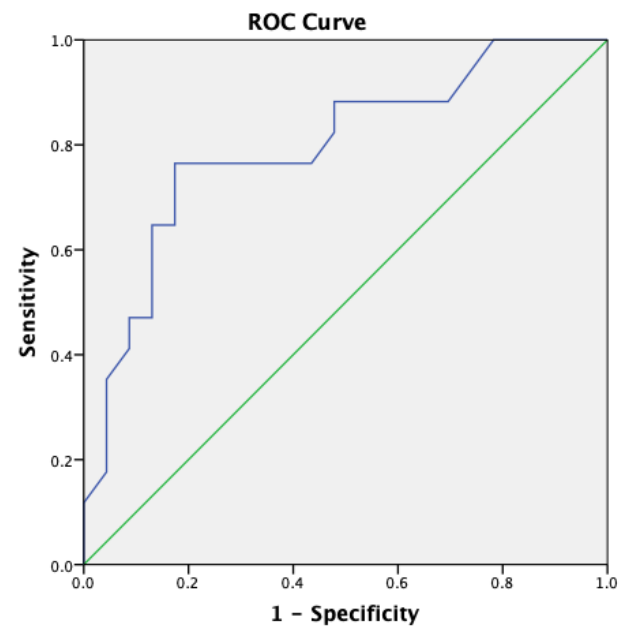

Diagonal segments are produced by ties.

Figure 2. FQRST with MPD ROC Curve

Table 2. Area Under The Curve of FQRST

\begin{tabular}{ccrccccc}
\hline $\begin{array}{c}\text { Para- } \\
\text { meters }\end{array}$ & AUC & $\begin{array}{r}\text { Cut- } \\
\text { off }\end{array}$ & p & Sens & Spec & NPV & PPV \\
\hline FQRST & $79,7 \%$ & $70^{\circ}$ & 0.002 & $70,6 \%$ & $82,6 \%$ & $75 \%$ & $79,1 \%$ \\
\hline
\end{tabular}

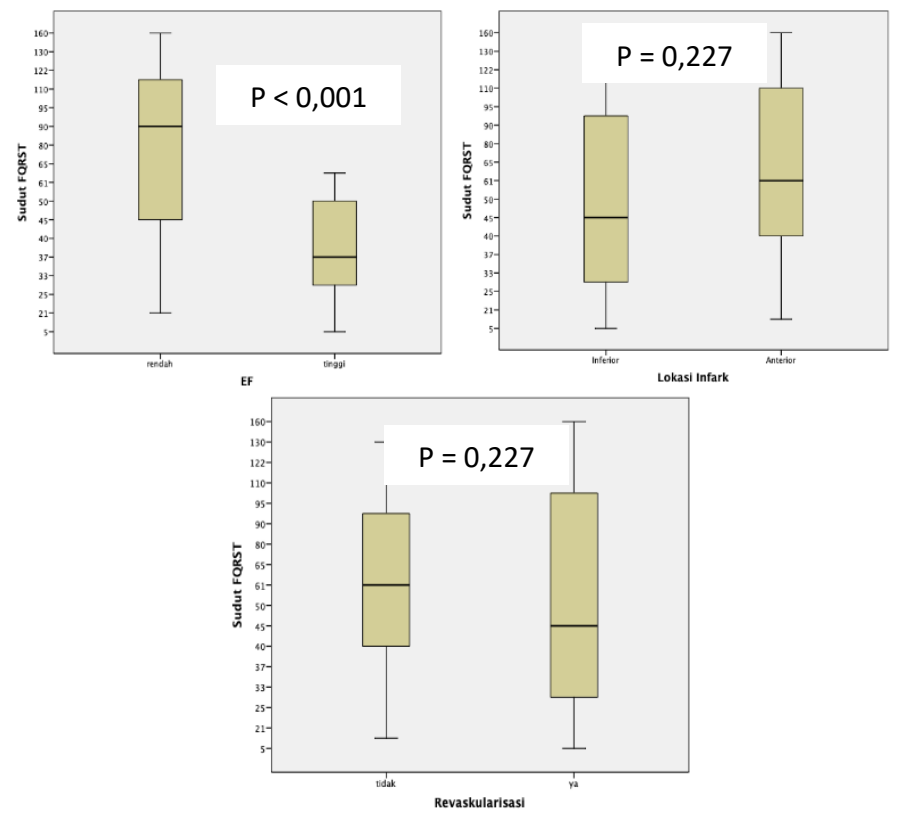

Figure 3. Relationship between frontal QRS-T angle (FQRST) with ejection fraction (EF), infarct location and revascularization.

\section{Discussion}

In this study we found the positive correlation $(\mathrm{p}<0,001)$ with moderate strength correlation $(r=0,543)$ between frontal QRS-T angle (FQRST) and myocardial perfusion defect (MPD) in STEMI patients. The previous study by Kurisu $S$ et.al suggested a similarity with a positive correlation $(\mathrm{p}<0,001)$ with moderate strength correlation $(\mathrm{r}=0,62)$ between FQRST and MPD in anterior STEMI. When the imbalance electrical activation and ventricular recovery occurred, the QRS axis and T wave axis no longer consistent so the QRS-T angle will be widened. Frontal QRS$\mathrm{T}$ angle would be easily measure by 12 leads ECG with the differences of absolute value between frontal QRS axis and frontal T wave axis. Frontal QRS-T axis is contributed with prediction of abnormal repolarization stages before direct ECG changes occurred, and proven to predict mortality in common population, diabetes mellitus, congestive heart failure and coronary artery disease patients. ${ }^{5}$ The abnormality of QRS-T angle may be correlated with underlying structural disease. A new present study showed patients with abnormal QRS-T angle have been suffered prior myocardial infarction often than patient with normal QRS-T angle in diabetic population. ${ }^{6}$ Sudden cardiac death mostly occurred due to ventricular arrythmia, over $50 \%$ of the other cardiovascular death. ${ }^{7}$ Previous study using cardiac magnetic resonance (CMR) as a diagnostic tools to analyzed the relationship of myocardial scar size and ventricular arrythmia, which was performed by ZeidanShwiri T et al. 2015, found patients with prior myocardial infarction who performed implantable cardioverter defibrillator (ICD), had been showed a grey zone and myocardial infarction center were a good predictor to determine the usage of ICD therapy effectively. ${ }^{8}$ Scott et al. 2013 cohort study reported that the wide area of left ventricular scar is associated with ventricular arrythmia in patients treated using ICD. ${ }^{9}$ The result of the several study shown the widen of QRS-T angle is comparable to myocardial perfusion defect (MPD) area size, as described in this study. Based on the previous study and our study, we suggest that frontal QRS-T angle might be useful to predict ventricular arrythmia in patient with previous STEMI history. Among female population, the risk of cardiovascular disease was shown if QRS-T angle $>60^{\circ}$. The risk was highly significant increased if the angle $>90^{\circ}$, and will be flattened over this angle. The risk will be increase with angle $>120^{\circ}$, and highly significant increase if the angle $>150^{\circ} .{ }^{10}$ Frontal QRS-T angle is calculated by measuring the difference between QRS-T wave axis and T-wave axis in $180^{\circ}$, with normal category $<90^{\circ}$, and abnormal $>100^{\circ} .11$ We found the cutoff point of frontal QRS-T angle to show Myocardial Perfusion Defect (MPD) was $\geq 70^{\circ}$, with $70,6 \%$ sensitivity and $82,6 \%$ specificity in predicting the wide area of myocardial infarct. Previous study was showed the cut-off point, sensitivity and specificity of frontal QRS-T angle. Darmawan IK 2019 showed the cut-off point of frontal QRS$\mathrm{T}$ angle to determine the left ventricle systolic dysfunction was $\geq 75^{\circ}$ with $81 \%$ sensitivity dan $87 \%$ specificity in acute heart failure patients. ${ }^{12}$ Kurisu et al, 2018 used frontal QRS$\mathrm{T}$ angle cut off point which have a high value in predicting myocardial perfusion defect in STEMI patient was $\geq 90^{\circ}$, as seen in Parvi et al, 2008 study.5,13 We found the mean of FQRST angle with preserved EF $(\geq 50)$ was low 37,80 \pm 17,54 , and mean FQRST angle with reduced EF $(<50)$ was high $84,24 \pm 40,35$ ( $p$ value $<0,001$ ). This is parallel with Darmawan IK 2019 study, which showed the EF $<40$ had mean FQRST $117 \pm 36$ and $\mathrm{EF} \geq 40$ had mean FQRST $47 \pm 40$ with $p$ value $<0,001.12$ The changes of QRS-T angle is due to fibrosis, excessive pressure and volume and ischemia. 
Repolarization is more specifics in consuming energy and ischemia in many mechanisms that shown unpredictable effect. ${ }^{14}$ This study found FQRST angle was larger in patient with anterior STEMI 72,5 $\pm 41,75$ over patient with inferior STEMI $56,2 \pm 36,82$ but it's not statistically significant (p value 0,227$)$. FQRST angle might be able to use to predict myocardial perfusion defect in both groups, but the subjects of our study were different. Patient with anterior STEMI was 26 people and inferior STEMI was 14 people. The broad difference between both groups was huge so we could not analyze the relationship of FQRST angle and MPD in our study. The study sample was relatively small. Further study is needed with larger sample. Pascale et al, 2009 found that subjects with inferior myocardial infarction was susceptible to ventricular arrythmia than patient with anterior myocardial infarction. ${ }^{15}$ Kurisu et al, 2020 found that FQRST angle was not elevated in patient with inferior myocardial infarction than in patient with anterior myocardial infarction. The reason of this was doubtful, but one of the reasons is the FQRST angle might not showed good spatial FQRST angle, especially in inferior myocardial infarction. FQRST angle was generated by projection of QRS and T vector with spatial three dimensional to frontal area. We need to confirmed that frontal QRS-T was projected QRS-T spatial angle in both anterior and inferior myocardial infarct. ${ }^{16}$ However, further study is needed to clarify the implication of FQRST angle to predict total mortality or ventricular arrythmia in anterior myocardial infarct and inferior myocardial infarct separately. There was no difference between FQRST angle to MPD either in both patients undergone revascularization or not. Over the countable, we found that FQRST angle in patients which performed revascularization $(64,8 \pm 44,53)$ is lower than not $(69,1 \pm 36,34)$. But the difference is not widely ranged. This might be because the revascularization was performed with onset $>12$ hours so it could not stop the infarct formation. Patients who undergo revascularization was 21 people, 5 people in onset $<12$ hours and 16 people in onset $>12$ hours.

\section{Conclusions}

In summary, we identified that frontal QRS-T angle have a positive correlation with moderate strength correlation to myocardial perfusion defect (MPD) in this study. The wider FQRST angle will show the higher myocardial perfusion defect in STEMI patients. We also found FQRST angle $\geq 70^{\circ}$ has a $70,6 \%$ sensitivity and $82,6 \%$ specificity to predict large infarct area (MPD $>22,8$ ). The limitations of this study are small sample size over another previous study, and only performed in single center. The further study is needed with larger sample size.

\section{References}

1. Fu C, Yao Y, Wang X, et al. Prognosis of patients with coronary artery disease treated in different therapy units at department of cardiology: a retrospective cohort study. Int J Clin Exp Med 2015;8(9):1565715665.

2. Info Datin. Situasi Kesehatan Jantung. Pusat Data dan Informasi Kementrian Kesehatan RI 2014.
3. Loffler AI, Kramer C.M. Myocardial viability testing to guide coronary revascularization. Interv Cardiol Clin. 2018 July ; 7(3): 355-365.

4. Smit JM, Hermans MP. Dimitriu-Leen AC, et al. Longterm prognostic value of single-photon emission computed tomography myocardial perfusion imaging after primary PCI for STEMI. European Heart Journal - Cardiovascular Imaging (2018) 19, 1287-1293.

5. Kurisu S, Nitta K, Sumimoto Y, et al. Myocardial perfusion defect assessed by single-photon emission computed tomography and frontal QRS-T angle in patients with prior anterior myocardial infarction. Springer 2018

6. May O, Graversen CB, Johansen MO, et al. A large frontal QRS-T angle is a strong predictor of the longterm risk of myocardial infarction and all-cause mortality in the diabetic population. J Diabetes Complicat. 2017 31:551-555

7. Huikuri HV, Castellanos A, Myerburg RJ. Sudden death due to cardiac arrhythmias. N Engl J Med. 2001; 345:1473-1482.

8. Zeidan-Shwiri T, Yang Y, Lashevsky I, et al. Magnetic resonance estimates of the extent and heterogeneity of scar tissue in ICD patients with ischemic cardiomyopathy predict ventricular arrhythmia. Heart Rhythm. 2015; 12:802-808

9. Scott PA, Rosengarten JA, Murday DC, et al. Left ventricular scar burden specifies the potential for ventricular arrhythmogenesis: an LGE-CMR study. J Cardiovasc Electrophysiol. 2013; 24:430-436

10. Gotsman I, Keren A, Hellman Y, et.al. Usefulness of Electrocardiographic Frontal QRS-T Angle to Predict Increased Morbidity and Mortality in Patients With Chronic Heart Failure. (Am J Cardiol 2013;111:1452e1459)

11. Aro, Aapo L, Heikki VH, et al. QRS-T angle as a predictor of sudden cardiac death in a middle-aged general population. Europace (2012) 14, 872-876

12. Darmawan IK. Sudut Gelombang QRS - T Bidang FrontalSebagaiPrediktor Disfungsi Sistolik Ventrikel KiriPadaPasienGagalJantungAkut 2019.

13. Pavri, Behzad B, Matthew BH, et al. Prognostic Value and Temporal Behavior of the Planar QRS-T Angle in Patients WithNonischemic Cardiomyopathy Circulation. 2008;117:3181-3186.

14. Rodriguez B, Trayanova N, Noble D. Modeling cardiac ischemia. Ann N Y Acad Sci 2006;1080:395414 [PubMed PMID: 17132797, Pubmed Central PMCID: PMC3313589, Epub 2006/11/30. eng].

15. Pascale P, Schlaepfer J, Oddo M, et al. Ventricular arrhythmia in coronary artery disease: limits of a risk stratification strategy based on the ejection fraction alone and im- pact of infarct localization. Europace 11: 1639-1646, 2009.

16. Kurisu S, Nitta $K$, Sumimoto $Y$, et al. Effects of Myocardial Perfusion Defect on the Frontal QRS-T Angle in Anterior Versus Inferior Myocardial Infarction. Intern Med 59: 23-28, 2020. 